\title{
TOOL USE IN DIGGER WASPS (HYMENOPTERA: SPHECINAE)*
}

\author{
By H. JANE BROCKMANN \\ Department of Zoology, University of Florida \\ Gainesville, FL 32611
}

\begin{abstract}
"Tool-use" by a digger wasp was first described by Williston (1892) and Peckham and Peckham (1898). They observed this remarkable behavior in two species of ground-nesting wasps, Ammophila urnaria and Ammophila aberti. The female digs a burrow in the ground, provisions it with paralyzed caterpillars, lays an egg on top of the food cache and then fills the burrow with soil or stones. While closing the nest, the wasp picks up a pebble in her mandibles and pounds the substrate with it, thereby compacting and settling the soil that was used to fill the nest. The Peckhams said that in this behavior, the wasp had "... improvised a tool and made intelligent use of it." The behavior received much publicity (see Frisch, 1940; Lamburn, 1955; Evans, 1959) and several authors saw tool using as evidence that wasps have highly plastic, intellectual powers (Rau and Rau, 1918; McDougall, 1923; Bouvier, 1922). Others have interpreted the behavior differently. Rather than thinking of tool using as insightful, they described the behavior as a species-typical, instinctive act (Holmes, 1911; Frisch, 1940; Baerends, 1941; Evans, 1959) or possibly an example of trial-and-error learning (Thorpe, 1956). Although some have questioned whether the behavior should be considered true tool use (Frisch, 1940; Evans, 1959), the action clearly falls under the current definition (Alcock, 1972; Wilson, 1975). When Ammophila uses a pebble as a hammer, she is manipulating an object, not internally manufactured, with the effect of improving her efficiency in altering the position, form or condition of some other object in the environment (Beck, 1980; Alcock, 1972). How did such extraordinary behavior evolve?
\end{abstract}

The Sphecidae are a large family of solitary (usually), hunting wasps. In general, the female constructs a nest which she provisions with one to several paralyzed arthropod prey as food for the single

* Manuscript received by the editor September 24, 1984. 
egg she lays in each brood cell. Most species dig holes in the ground, but some nest in pre-existing cavities whereas others construct mud nests. Regardless of the type of nest, all species of sphecids show some sort of final nest closure. This nearly always includes behavior that apparently compacts or settles the material used. Most sphecids and pompilids (spider wasps) pack the soil by repeatedly tapping or pounding on the substrate with the last abdominal segment (Carpenter, 1930; Evans, 1966b), often while simultaneously vibrating the abdomen (Endo, 1981). However, one subfamily of sphecids, the Sphecinae, differs in that they tamp or press the soil with the front of the head. It is in this group that tool-using behavior has evolved. In this paper I examine the frequency, origin and adaptive value of tool using in the Sphecinae.

Throughout the following discussion of nest closure in the Sphecinae, I include observations I have made on various species. Descriptions of Sphex ichneumoneus come from notes, slides and films taken during a five-summer study (July-August) at sites in Dearborn, MI (1972-75, an aggregation of 73 individually marked wasps was observed completing 200 final closures over the four years), Exeter, NH (1975, 33 wasps and 60 permanent closures) and Northfield, $M N(1976,136$ wasps and 150 closures) (see Brockmann 1979 and Brockmann and Dawkins 1979 for further details). The great black wasp, Sphex pensylvanicus, was observed in 1974 (25 Aug$16 \mathrm{Sep}$ ) at a gravel pit near Rensselaerville, NY (25 individually marked wasps and 12 final closures were observed). Brief observations of Ammophila urnaria were made at the same site ( 3 wasps, 2 nest closures). One observation of nest closing was made on Podalonia pubescens, Ammophila wrightii and A. breviceps near the Southwestern Research Station, Portal, AZ (30 May-22 June 1975). Ammophila aberti was observed briefly at Chaco Canyon National Monument (10 wasps seen, one nest closure, 30 June 1975). Brief observations on $A$. aureonotata and $A$. pictipennis were made at the Archbold Biological Station, Lake Placid, FL (14-17 April 1974).

\section{Nest Closure}

The ground-nesting Sphecinae generally construct a simple nest: a long, straight, main-tunnel with a perpendicular side-tunnel and terminal brood chamber. They dig the nest by biting at the substrate and scraping away the loosened soil with rakes on their front tarsi 
(Brockmann, 1980). Unlike other members of the family, all Sphecinae gather up the loosened soil into a ball and carry it out of their burrow, holding the bolus up under the head with their front legs, while walking on the middle and hind legs (Olberg, 1959; Evans and West Eberhard, 1970; Brockmann, 1980). In most species the wasp drops her load immediately outside the nest entrance, which results in a mound or tumulus. This accumulated soil is later used for filling the burrow after the provisioning is complete. In contrast with this, Ammophila usually flies up with the armload of soil and drops it some distance from the nest entrance (Table 1A; Evans, 1959). Some Ammophila walk out of the nest carrying armloads of soil, but then drop them away from the nest entrance, usually in different directions (Table 1A). The effect of this is that the Ammophila do not usually have a distinct mound from which they can fill their nest during the final closure, as do other ground-nesting Sphecinae.

There are four stages to nest-closure and each involves different kinds of behavior (Table 1A; Evans, 1959). (1) The wasp closes off the chamber or blocks the bottom of her burrow, and then (2) fills in the main tunnel. (3) When the tunnel is nearly filled, she blocks off or levels the soil in the entrance and then (4) disguises the location of her nest. Most species of Sphecinae do not show a distinct closure at the bottom of the burrow, but rather begin immediately by filling the side and main tunnels with soil (Table 1A). Ammophila, on the other hand, does not usually fill the short side-tunnel but blocks the bottom of the main tunnel by adding a single large or several small stones, clods of soil, sticks or other debris. Sphecinae fill the main shaft of the burrow by adding soil, by alternating soil and stones or by adding just stones (a few species use mud) (Table 1B). In nearly all species these materials are alternately added and packed. Most wasps remove some objects such as large stones, sticks and leaves, as they scrape and pack. They do this by pushing the object aside with their mandibles, by picking it up with the mandibles and depositing it to one side of the nest entrance or flying up and releasing it at some distance (Frisch, 1937, 1940; Evans, 1959; personal observation).

There are four different kinds of filling behavior used by the Sphecinae (most species use some combination of these four methods). (1) Standing at the nest entrance, the wasp scrapes soil underneath her and into the burrow with her front legs "dog- 
Table 1A. The behavior used in permanent nest-closure by the ground-nesting Sphecinae $(X=$ observed, $S=$ sometimes observed, $?=$ not known due to incomplete observations, $-=$ not observed).

\section{Digging Behavior}

Method of Digging

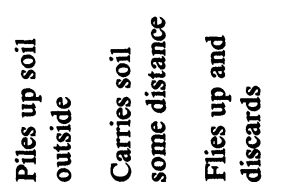

Method of Filling the Nest

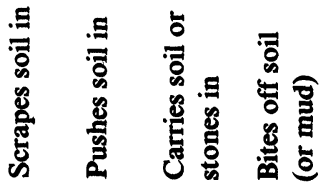

Species

\begin{tabular}{|c|c|c|c|c|c|c|c|}
\hline \multicolumn{8}{|l|}{ Sceliphrini } \\
\hline Stangeella cyaniventris & $\mathbf{X}$ & - & - & $\mathbf{X}$ & - & $\mathbf{X}$ & - \\
\hline Penepodium Luteipenne & $\mathbf{X}$ & - & - & - & - & $\mathbf{X}$ & $\mathbf{X}$ \\
\hline \multicolumn{8}{|l|}{ Sphecini } \\
\hline Sphex argentatus & $\mathbf{X}$ & - & - & $\mathbf{X}$ & $\mathbf{X}$ & - & - \\
\hline Sphex ichneumoneus & $\mathbf{X}$ & - & - & $\mathbf{X}$ & $\mathbf{X}$ & - & $\mathbf{X}$ \\
\hline Sphex muticus & $\mathbf{X}$ & - & - & $\mathbf{X}$ & - & - & - \\
\hline Sphex pensylvanicus & $\mathbf{X}$ & - & - & $\mathbf{X}$ & $\mathbf{X}$ & - & $\mathbf{X}$ \\
\hline Sphex subtruncatus & $\mathbf{X}$ & - & - & $\mathbf{X}$ & - & - & $\mathbf{x}$ \\
\hline Sphex Fernaldina lucae & $\mathbf{X}$ & - & - & $\mathbf{X}$ & $\mathbf{X}$ & - & - \\
\hline Palmodes dimidiatus & $\mathbf{X}$ & - & _- & $\mathrm{X}$ & - & - & $\mathbf{X}$ \\
\hline Palmodes laeviventris & $\mathbf{X}$ & - & - & $\mathbf{X}$ & - & $\mathbf{X}$ & - \\
\hline Prionyx atratus & $\mathbf{X}$ & - & - & $\mathbf{X}$ & - & - & $\mathbf{X}$ \\
\hline Prionyx kirbii & $\mathbf{X}$ & - & - & $\mathbf{X}$ & - & $\mathbf{X}$ & - \\
\hline Prionyx subfuscatus & $\mathbf{X}$ & - & - & $\mathbf{X}$ & - & - & - \\
\hline Prionyx thomae & $\mathbf{X}$ & - & - & $\mathbf{X}$ & - & $\mathbf{X}$ & $\mathbf{X}$ \\
\hline Prionyx viduatus & $\mathbf{X}$ & - & - & $\mathbf{X}$ & - & - & - \\
\hline \multicolumn{8}{|l|}{ Ammophilini } \\
\hline Podalonia spp. & $\mathbf{X}$ & - & - & $\mathbf{X}$ & - & - & - \\
\hline Podalonia hirsuta & $\mathbf{X}$ & - & - & $\mathbf{x}$ & - & $\mathbf{X}$ & - \\
\hline Podalonia luctuosa & $\mathbf{X}$ & - & - & $\mathbf{X}$ & - & $\mathbf{X}$ & - \\
\hline Podalonia pubescens & $\mathbf{X}$ & - & - & $\mathbf{X}$ & - & - & - \\
\hline Podalonia violaceipennis & $\mathbf{X}$ & - & - & $\mathbf{X}$ & - & - & $\mathbf{X}$ \\
\hline Eremochares dives & $\mathbf{X}$ & - & - & $\mathbf{X}$ & - & - & $\mathbf{X}$ \\
\hline Eremnophila aureonotata & - & - & $\mathbf{X}$ & $\mathbf{X}$ & - & - & - \\
\hline Ammophila aberti & - & - & $\mathbf{X}$ & $\mathrm{X}$ & - & $\mathbf{X}$ & - \\
\hline Ammophila azteca & - & - & $\mathbf{x}$ & $\mathbf{x}$ & - & $\mathbf{X}$ & $\mathbf{x}$ \\
\hline Ammophila clavus & - & - & $\mathbf{X}$ & $\mathbf{x}$ & - & $\mathbf{X}$ & - \\
\hline Ammophila harti & - & - & $\mathbf{X}$ & $\mathbf{X}$ & - & $\mathbf{X}$ & - \\
\hline Ammophila heydeni & - & - & $\mathbf{X}$ & $\mathbf{X}$ & - & $\mathbf{X}$ & $\mathbf{X}$ \\
\hline Ammophila juncea & - & - & $\mathbf{X}$ & $\mathbf{X}$ & - & $\mathbf{X}$ & - \\
\hline Ammophila kennedyi & - & $?$ & $?$ & $\mathbf{X}$ & - & $\mathbf{X}$ & - \\
\hline Ammophila macra & - & $\mathbf{X}$ & $\mathbf{X}$ & $\mathbf{x}$ & - & - & $\mathbf{X}$ \\
\hline Ammophila pictipennis & - & $\mathbf{X}$ & $\mathbf{S}$ & $\mathbf{X}$ & - & $\mathbf{X}$ & $\mathbf{X}$ \\
\hline Ammophila placida & - & $\mathbf{S}$ & $\mathbf{x}$ & $\mathbf{x}$ & - & $\mathbf{X}$ & $\mathbf{X}$ \\
\hline Ammophila procera & - & $\mathbf{S}$ & $\mathbf{X}$ & $\mathbf{X}$ & - & $\mathbf{X}$ & $\mathbf{X}$ \\
\hline Ammophila pruinosa & - & $\mathbf{S}$ & $\mathbf{X}$ & $\mathbf{X}$ & - & $\mathbf{X}$ & - \\
\hline Ammophila pubescens & - & $\mathbf{S}$ & $\mathbf{X}$ & $\mathbf{X}$ & - & $\mathbf{X}$ & $\mathbf{X}$ \\
\hline Ammophila sabulosa & - & $\mathbf{S}$ & $\mathbf{X}$ & $\mathbf{x}$ & - & $\mathbf{X}$ & - \\
\hline Ammophila urnaria & - & $\mathbf{X}$ & $\mathbf{S}$ & $\mathbf{X}$ & - & $\mathbf{X}$ & $\mathbf{X}$ \\
\hline Ammophila wrightii & - & $\mathbf{X}$ & - & $\mathbf{X}$ & - & $\mathbf{X}$ & $\mathbf{X}$ \\
\hline Ammophila zanthoptera & - & $\mathbf{X}$ & - & $\mathbf{X}$ & - & $\mathbf{X}$ & $\mathbf{X}$ \\
\hline
\end{tabular}

*Stone, stick, seed or other hard object 


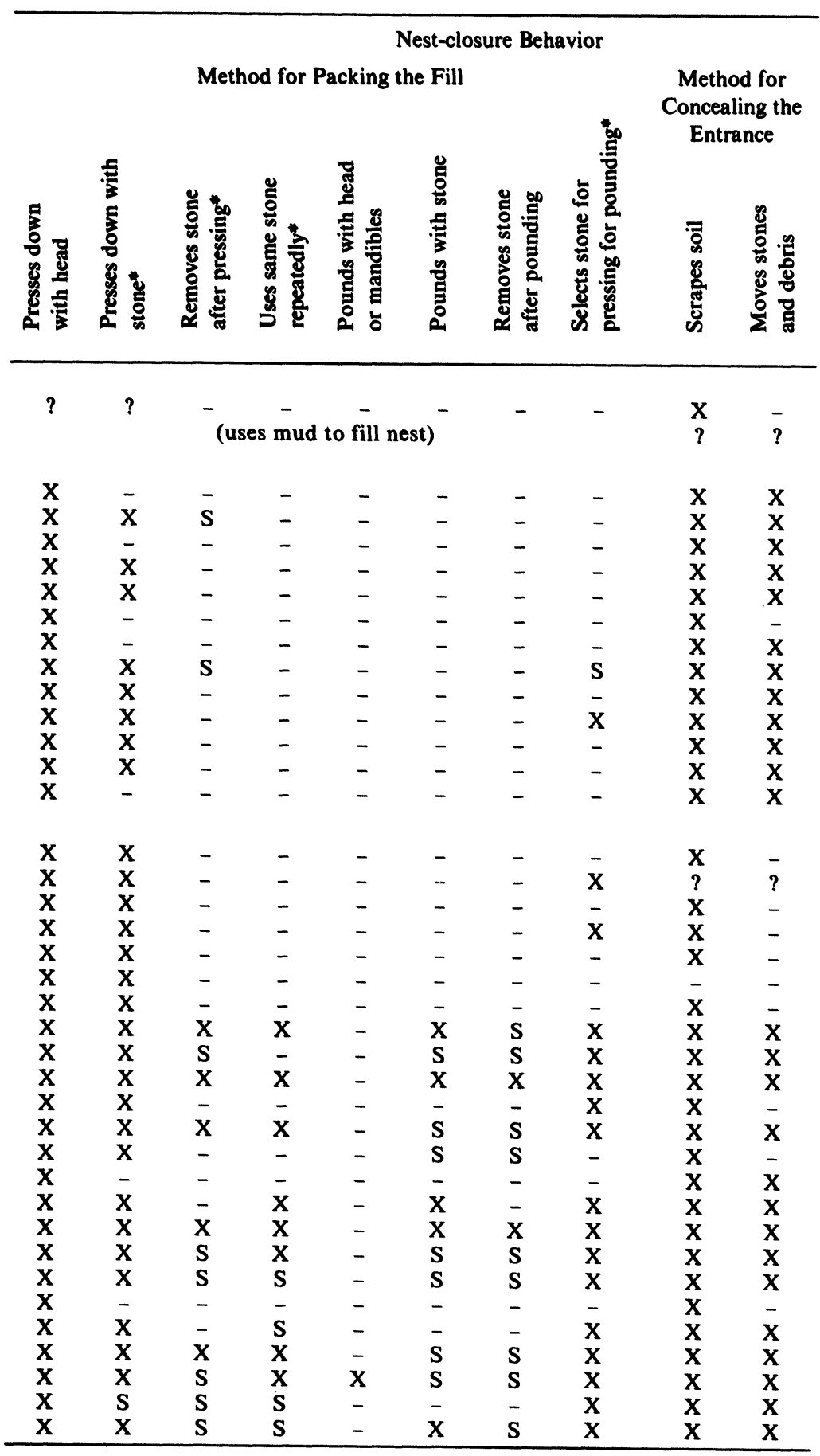


fashion" (Fig. 1; Olberg, 1959). (2) She bites at the soil around the nest entrance, and scrapes the loosened material into her nest. These are the same scraping and biting movements that are used during digging, only the body is now oriented away from the nest rather than toward it. (3) The wasp may also nudge or push soil ahead of her into the burrow with the front of her head (Fig. 2; Tsuneki, 1963; Cazier and Mortenson, 1965). (4) Some wasps pick up clods of soil, clumps of sand or stones in the mandibles and drop or place them in the nest (Carpenter, 1930; Adriaanse, 1943), often pressing them into the substrate (Fig. 3). In most species the wasp fills her nest with soil from the mound that accumulated at the nest entrance during digging (Sphex, Prionyx, Palmodes, Podalonia; Parker, 1915). However, in Ammophila where there is no mound, much of the burrow is filled with stones and debris found around the nest which are picked up and placed in the burrow. Soil is also chewed from the surrounding substrate and scraped in. Biting and scraping at the soil around the nest also occurs in Sphex when the mound is insufficient to completely fill the main tunnel. This is particularly common in $S$. pensylvanicus which digs exceptionally long, multichambered nests which it occupies for many days. When females of this species finally come to filling the main tunnel, the mound has often disappeared. She chews soil from around the nest entrance, often breaking down the sides of the tunnel and leaving a wide depression where the entrance once was. When there is more than one brood chamber in a nest (Sphecini), soil from digging the next side tunnel may be used to close off the previous one. (Ammophilini have only one brood cell in a nest.) A few species (A. placida, $A$. zanthoptera and $A$. pubescens) have been observed to dig "false burrows" or "mines" during nest closure, using the dug material to fill their nest (Adriaanse, 1943; Evans, 1959, 1966c). Adriaanse (1943) suggested that in $A$. pubescens the building of a mine was associated with a lack of suitable material for closing at the surface. I have observed similar behavior in Sphex ichneumoneus when they do not have enough soil on the mound with which to close the nest. This can occur after a rain or when another female has filled her nest with soil from her neightbor's mound (similar behavior has been described for other Sphex by Iwata, 1976).

Wasps complete the burrow filling by either continuing to add and pack soil, by piling up stones, by packing stones into a kind of 
pavement, or by pushing stones, sticks, leaves or other debris into the nest entrance (Table 1B). Finally, the wasps disguise the location of the nest by scraping soil in the vicinity and by moving leaves, sticks and other debris in the area over or near the nest entrance (Fig. 4; Table 1A). Some wasps do not perform this disguising behavior at all, whereas others move a few objects around in a perfunctory manner and still others spend long periods of time carefully concealing the nest entrance (Evans, 1959; Peckham and Peckham, 1898). Like other aspects of nesting behavior, nest-closure is highly variable, with individuals sometimes spending long periods of time filling, whereas at other times they only partially fill the burrow or do little packing (Adriaanse 1943; Tsuneki, 1968; Ristich, 1953; Hartman, 1905; personal observation).

The Sphecinae that dig the nest before hunting usually have some sort of temporary nest closure while they are away from the nest. Ammophila usually cover the nest at the surface with a pebble or piece of debris selected to fit the burrow entrance precisely (Evans, 1959, 1965). Sphex scrapes and nudges a little soil across the entrance to the side-tunnel, but leaves the main-tunnel open while they are out hunting. At the end of the day, most Sphex close off the nest overnight, digging it out again in the morning. This temporary overnight closure differs from the final closure in that the wasp quickly scrapes loose soil into the burrow, turning around to pack only occasionally and for shorter periods of time. In contrast with this, during the final nest closure, the wasp alternates a few scrapes of soil into the nest followed by long bouts of intensive packing (Fig. 3 ). The result is that the soil in the temporary closure is loose whereas in the permanent closing the soil is tightly compacted. When excavating even a recently closed nest, it is very difficult to distinguish the soil of the closure from the surrounding soil.

\section{Packing Behavior}

There are three general methods of packing soil into the burrow which grade into one another. (1) The wasp applies the clypeus and open mandibles to the substrate and pushes or presses down on the soil, usually while making low amplitude, high frequency vibrations of the head and body (Fig. 3). The body is normally angled well below the vertical; the wasp may raise her head and then press down again repeatedly within a short period of time at the same or slightly different spot. This action seems to grade into pounding. (2) The 

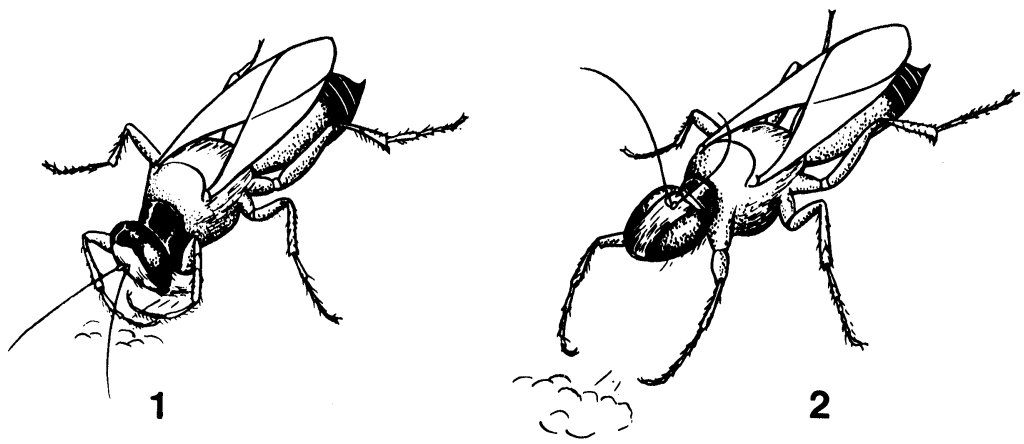

Fig. 1. Sphex ichneumoneus filling her nest. The wasp stands at the nest entrance (facing away) and scrapes soil between her legs, using the tarsal rakes on her prothoracic legs. She starts close to the nest entrance and gradually works her way up the mound. This means that early in a bout of scraping, the soil is flung into the burrow, whereas later the soil lands close to the nest entrance, and is thrown into the burrow during the next bout of scraping. Scraping is accompanied by frequent biting at the substrate with the mandibles to loosen the soil. The same behavior was observed in Sphex pensylvanicus.

Fig. 2. Sphex ichneumoneus nudges soil into her burrow. After scraping, the wasp turns around and walks down the mound toward her burrow. She often pauses at the nest entrance and nudges at the soil around the lip of the burrow. She pushes the soil ahead of her using the front of the mandibles and clypeus in quick, short, posterior to anterior motions of the head. Similar nudges were observed in $S$. pensylvanicus. 

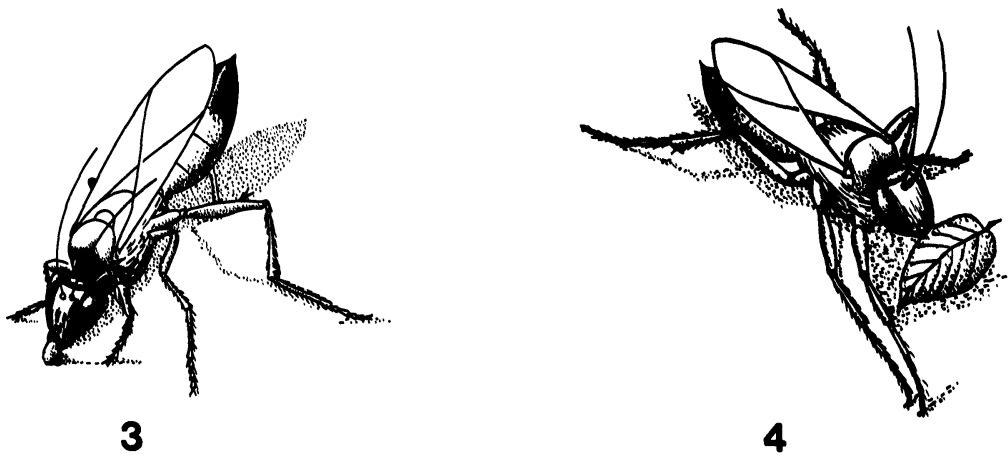

Fig. 3. S. ichneumoneus packing soil. After a bout of 5-15 seconds of scraping, the wasp enters her nest and packs the soil. She applies the open mandibles and oral surface of the head to the substrate and presses down for one half to two seconds, vibrating her head and body intensely. She occasionally raises one or both hind legs above the substrate. After 5-20 sec of packing she then reemerges at the surface for another bout of scraping. Late in the filling process, when the nest fill is within $1 \mathrm{~cm}$ of the surface, the wasp engages in particularly intense and prolonged packing. In addition to pressing on the fill, she also picks up stones, sticks, clods of dirt, or other pieces of debris, carries it to the nest in her mandibles and presses it down into the soil (seen here). Clods of dirt usually disintegrate, whereas stones and debris are either left in place or occasionally picked up and discarded. On rare occasions wasps have been observed to use the same object several times as a compacting tool. $S$. pensylvanicus shows similar packing behavior.

Fig. 4. S. ichneumoneus disguising the nest entrance. The wasp scrapes the region around the nest many times. Leaves, sticks and other debris are grasped with the mandibles and either pulled (seen here) over or pushed to the nest entrance or just picked up and moved to another location around the nest. The effect of this is that the exact location of the entrance is impossible to detect either by the degree of compaction of the soil or by the appearance of the area around the nest. Sphex pensylvanicus often chews around the nest entrance, breaking down the sides of the burrow and leaves a wide depression at the site of the nest entrance. 
wasp pounds the substrate by rapidly raising and lowering the head and body. The pressing and pounding behavior differ in the amount of time that the mandibles spend in contact with the substrate and in the height to which the wasp raises her head between substrate contacts. (3) The wasp assumes a nearly vertical position, applies the front of the head to the substrate and vibrates (high amplitude, high frequency) the entire head and body like a sort of pile driver. This behavior has been described explicitly only for $A$. procera (Wheeler and Wheeler, 1924; Evans, 1959). This behavior seems to differ from pressing by the angle of the body (although pressing with the body in a nearly vertical position can occur in any species depending on substrate conditions and whether she is in the burrow or not), the amplitude of the vibrations and the long, continuous time that the head is in contact with the substrate. Any of these packing movements may be accomplished with the mandibles alone or while holding a stone, clump of soil, stick or piece of debris (i.e. tool use). (Some species combine these packing methods.) Most Sphecinae pick up a stone, clod of dirt, leaf, twig or other object, apply it to the substrate and push down while vibrating. This action serves either to embed the object or to pack the underlying soil or both. If the object is friable, the pressure and vibration serve to disintegrate it. Sometimes, and with some species more commonly than with others, wasps remove the object after having pressed it into the substrate and use it again or discard it to one side of the nest entrance ('Table 1A; Peckham and Peckham, 1898; Rau and Rau, 1918; Evans, 1959; Evans and West Eberhard, 1970).

Tapping or pounding is a far less common form of packing behavior than pressing (Table 1A). Repeated tapping of the substrate with the oral surface of the head has been observed in several species of trap-nesting and mud-daubing Sphecinae (Rau, 1937; Iwata, 1938; Tsuneki 1963b, 1968; Krombein, 1970; personal observation). While pounding some species of Ammophila hold a stone in the mandibles, thereby giving the appearance of using a hammer (Williston, 1892; Peckham and Peckham, 1898; Rau and Rau, 1918; Wheeler and Wheeler, 1924; Evans, 1959, 1963, 1965; Powell, 1964; Evans and West Eberhard, 1970). The same stone is often used repeatedly and some authors describe the wasp as carefully selecting her hammer, picking up and discarding many stones before settling on one. 


\section{Origin and Adaptive Significance of Tool Use}

The preceding review of nest-closing behavior reveals that "tool use" is widespread among the Sphecinae, and is not limited to the Ammophila (Table 1A). Many species pick up stones and press and vibrate them down into the substrate during nest closure, an action that almost certainly serves to compact the underlying soil at the nest entrance (Newcomer, 1930; Frisch, 1940; Spangler, 1973; personal observation). Whether the object is removed or not, whether it is used repeatedly or only once, whether the wasp pounds or pushes with it, the result is almost certainly the same. If the stone is not removed, then in addition to being used as a compacting tool, it serves to block the nest entrance at the surface. The origin of this tool-using behavior among digging wasps coincides with the evolution of packing by means of the head and mandibles rather than the abdomen. Most species of Sphecinae which have been observed to pack soil with their mandibles have been observed to manipulate and press stones or other objects into the substrate (Table 1A). Evans (1959) describes a gradual progression from packing movements involving only the mandibles, to packing by pressing down with a stone, to the more complex pattern of pounding with a pebble which is later discarded. Table $1 \mathrm{~A}$ demonstrates that pounding with a stone is confined to some species of Ammophila, whereas pressing and pressing while holding an object are found among most of the ground-nesting Sphecinae. The intriguing question now becomes, what is the adaptive significance of these different sorts of packing techniques?

Several hypotheses have been proposed to explain the origin of the pounding-with-a-stone behavior found in Ammophila. Rau and Rau (1918) and Hicks (1932b) suggest that the availability of stones affects the frequency of pounding behavior in Ammophila. However, Table $1 \mathrm{~A}$ and $1 \mathrm{~B}$ reveal no association between the material used in nest closure and the kind of packing behavior. Eleven species of Ammophila use stones during nest closure, nine pound, two do not; six species do not use stones (or use only small pebbles) and three pound while three do not $\left(\chi^{2}=0.67, \mathrm{p}=0.4, \mathrm{df}=1\right)$. Evans (1959) suggests that species such as $A$. aberti and $A$. zanthoptera which nest in compactable soil, show frequent pounding behavior whereas those living in sandy soils that resist compaction (such as $A$. harti) do not. He argues that $A$. urnaria and $A$. juncea which nest in 


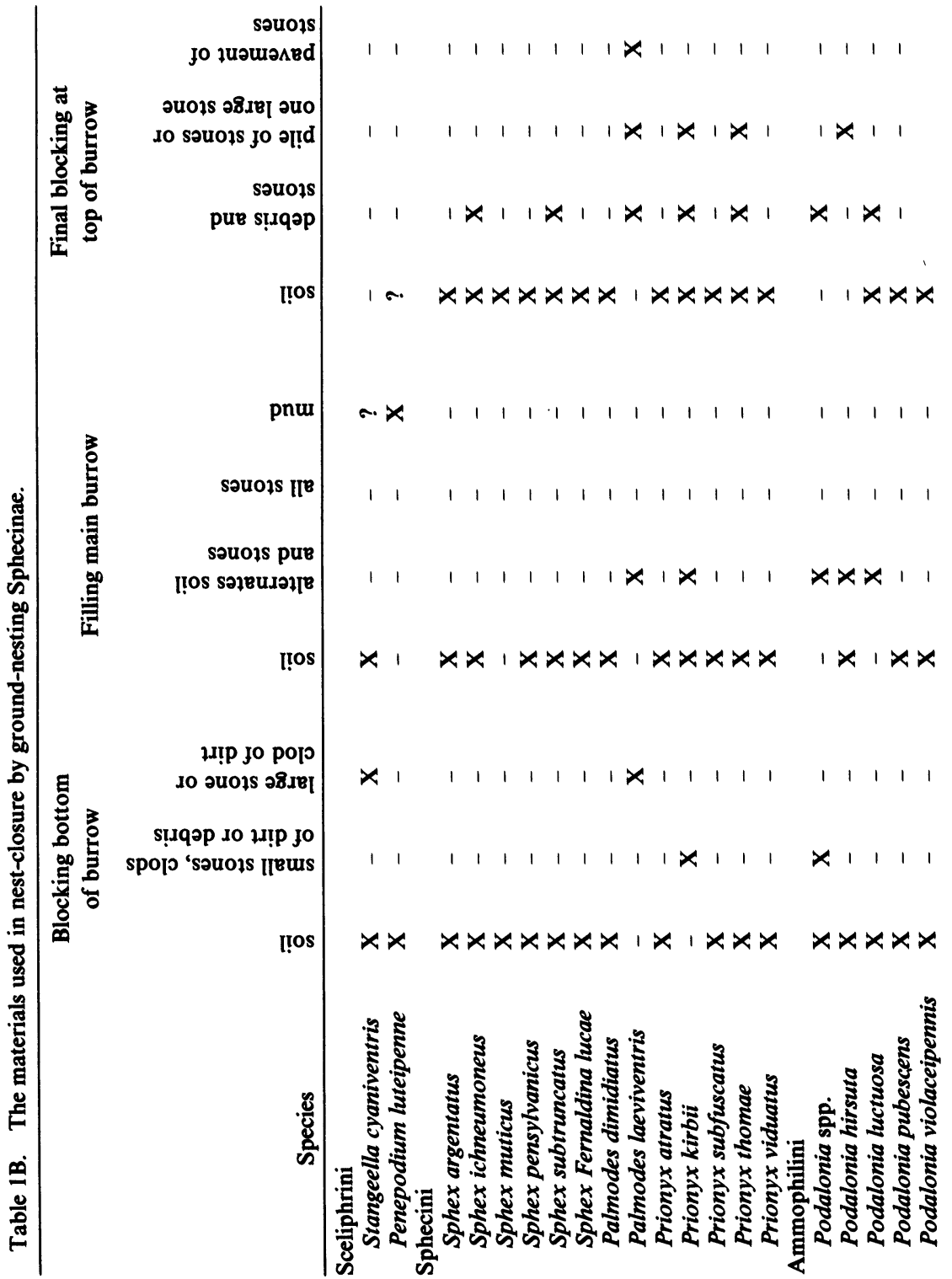




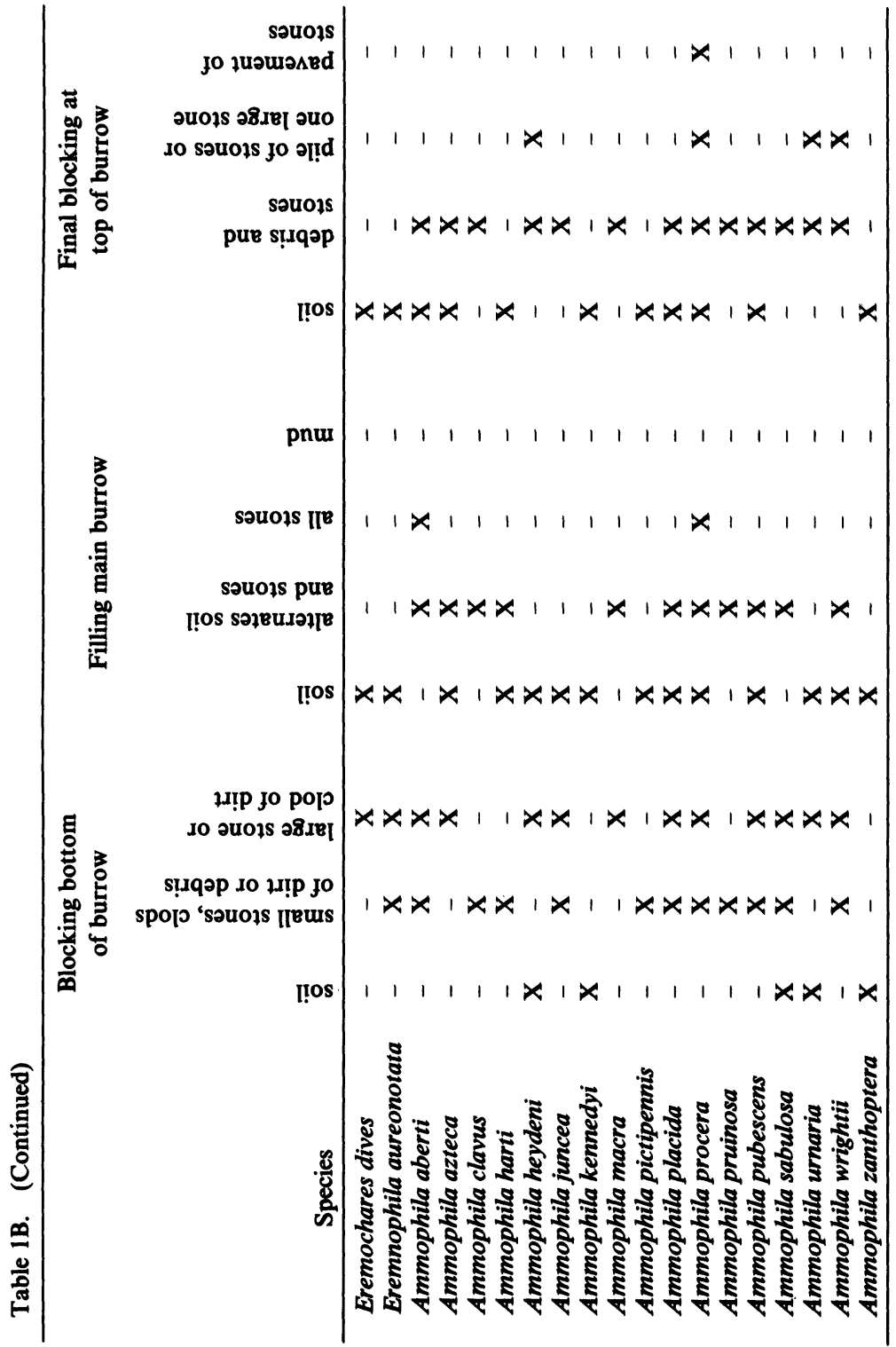


a wide range of soils show highly variable tool-using behavior, pounding when nesting in compactable soil and not when nesting in sand (Peckham and Peckham, 1898; Thorpe, 1956). Unfortunately, the data were too sparse to include substrate in Table 1 and hence no test of this hypothesis is possible at present. However, it is possible to say that while this association may hold within the Ammophila, it does not explain the diversity of packing behavior found among the ground-nesting Sphecinae. I have observed two species of Sphex (S. ichneumoneus, $S$. pensylvanicus) and one species of Ammophila (A. urnaria) nesting side-by-side and only the Ammophila showed the pounding behavior. Table $1 \mathrm{~A}$ reveals that this behavior is unique to Ammophila-but this is not the only unique behavior found in the genus. They also dig their burrows in quite a different manner from the other Sphecinae, depositing soil at some distance from the nest entrance. Therefore, Ammophila have no mound of soil from which to scrape nest fill and they must use whatever they can find around the nest. Some of these objects are not particularly appropriate for the purpose and may require more persistent and strenuous packing to achieve the same level of compaction; certainly hunting around for objects takes more time than simply filling from the mound (Adriaanse, 1943). Sphex, on the other hand, (and other species with a mound) have a ready supply of suitable material with which they can rapidly fill their nest. It might also be noted that Ammophila are particularly slender, light-bodied wasps (as compared with other Sphecinae) and it may be difficult for these animals to apply any significant force to the substrate without the added weight of a stone (which can be as much as ten times the weight of the wasp, Iwata, 1976).

No one has ever demonstrated the survival value of packing for digger wasps, although there is no doubt that they expend considerable time and effort in carefully compacting the fill and disguising the location of the nest entrance. There are no observations of parasites or predators digging into closed nests, although the very common parasitic flies (Sarcophagidae) and velvet ants (Mutillidae) must be able to dig their way out. I have observed several species working their way in through temporary closures of Sphex ichneumoneus, including various species of ants (which rob the nest of its provisions), a cleptoparasitic sphecid, Nysson plagiatus, and possibly sarcophagid flies (Senotainia trilineata) and cuckoo wasps 
(Chrysis) (they certainly enter Sphex nests frequently) (see also Evans, 1966a). The most common marauders, however, are conspecifics which regularly dig up the temporarily filled nests of neighbors. They sometimes discard the contents of the brood chamber when they encounter it or they may take over the nest and use the provisions for their own offspring (Brockmann and Dawkins, 1979). Occasionally a wasp will dig her burrow into the completed nest of another female, and when she does she pulls out the contents (be they provisions or pupa), flies up and discards them away from the nest. In a study of nest-site selection in Sphex ichneumoneus (Brockmann, 1979), I observed wasps biting repeatedly at different spots on the substrate. They would finally begin to dig when they encountered a spot that gave way to their chewing, i.e. a spot that was slightly less compacted. Therefore, it seems likely that one important selective pressure acting on the final-closure behavior is reducing the chance that another female will dig in the exact same location. This may be particularly crucial in species that regularly nest in aggregations.

Once the survival value of packing is known, then it may be possible to assess the value of different packing methods to different species of wasps. Far more information is needed on the nature of the nesting substrate, the details of the packing behavior, the consequences of the various packing methods on different soils and the behavior of parasites, predators and conspecifics when digging under different conditions of compaction.

\section{ACKNOWLEDGMENTS}

I would like to thank Benjamin Beck for reading an earlier version of this manuscript and Howard Evans for identifying specimens. Cheryl Hughes and Paloma Ibarra prepared the drawings from slides and films. Giulio Genoni translated papers written in German. I also wish to thank Orin Gelderloos and the University of Michigan-Dearborn, Richard and Betty Brinckerhoff of Exeter, New Hampshire, Harry and Olga Olson of Rensselaerville, New York, Gary Wagenbach and Carleton College of Northfield, Minnesota, the Southwestern Research Station in Portal, Arizona and the Archbold Biological Station in Lake Placid, Florida for providing the opportunity to study digger wasps. Equipment and advice were provided by Jack P. Hailman and funding was provided by the 
Theodore Roosevelt Memorial Fund and the Department of Zoology, University of Wisconsin, Madison.

\section{References Cited}

AdriaAnse, $A$.

1943. Ueber eine lokale Verhaltensvariation beim Offnen und Schliessen des Nestganges durch Ammophila campestris Jur. (Hym.) Entomol. Ber. 11: 69-78.

ADRIAANSE, A.

1947. Ammophila campestris Latr. und Ammophila adriaansei Wilcke ein Beitrag zur vergleichenden Verhaltensforschung. Behaviour 1: 1-34.

Ainslie, C. N.

1924. Note on the nesting habits of Chlorion elegans. Can. Entomol. 56: 269-270.

Alcock, J.

1972. The evolution of the use of tools by feeding animals. Evolution 26: 464-473.

BAERENDS, G. P.

1941. Fortpflanzungsverhalten und Orientierung der Grabwespe Ammophila campestris Jur. Tijdschr. Entomol. 84: 68-275.

BECK, B. B.

1980. Animal Tool Behavior: The Use and Manufacture of Tools by Animals. Garland Press, New York.

BENZ, G.

1959. Beobachtungen uber das brutbiologische Verhalten von Sphex albisectus, Lepeletier (Hym. Sphegidae). Vierteljahrsschrift der Naturforschende Gessellschaft in Zurich. 104: 307-319.

Bohart, R. M. AND A. S. Menke

1963. A reclassification of the Sphecinae with a revision of the nearctic species of the tribes Sceliphronini and Sphecini. Univ. Calif. Publ. Entomol. 30: 91-181.

1976. Sphecid Wasps of the World: a Generic Revision. University of California Press. Berkeley, California.

BOUVIER, E. L.

1922. The Psychic Life of Insects. The Century Co., New York.

BrockmanN, H. J.

1976. The control of nesting behavior in the great golden digger wasp, Sphex ichneumoneus. Ph.D. Dissertation, University of Wisconsin, Madison, Wisconsin.

1979. Nest-site selection in the great golden digger wasp, Sphex ichneumoneus L. (Sphecidae). Ecol. Entomol. 4: 211-224.

1980. The control of nest depth in a digger wasp (Sphex ichneumoneus L.). Anim. Behav. 28: 426-445.

Brockmann, H. J. AND R. Dawkins

1979. Joint nesting in a digger wasp as an evolutionarily stable preadaptation to social life. Behaviour 71: 203-245. 
CARPENTER, G. D. H.

1930. Psammocharidae (Pompilidae) and Sphecidae. Collected records of their different methods of filling the stocked burrow. Trans. Royal Entomol. Soc. London 78: 283-304.

Cazier, M. A. and M. A. Mortenson

1965. Studies on the bionomics of sphecoid wasps. VI. Fernaldina lucae (Hymenoptera: Sphecidae). Pan-Pac. Entomol. 41: 34-43.

Endo, A.

1981. Nesting success of the spider wasp, Episyron arrogans (Smith) (Hymenoptera, Pompilidae) and the effect of interactions with other insects around its nesting site. Physiol. Ecol. Japan 18: 39-75.

Evans, H. E.

1958. Studies on the nesting behavior of digger wasps of the tribe Sphecini. Part I: Genus Priononyx Dahlbom. Ann. Entomol. Soc. Amer. 51: 177-186.

1959. Observations on the nesting behavior of digger wasps of the genus Ammophila. Amer. Midl. Natur. 62: 449-473.

1963. Wasp Farm. Natural History Press, New York.

1965. Simultaneous care of more than one nest by Ammophila azteca Cameron (Hymenoptera, Sphecidae). Psyche 72: 8-23.

1966a. The Comparative Ethology and Evolution of the Sand Wasps. Harvard University Press, Cambridge, Massachusetts.

1966b. The behavior patterns of solitary wasps. Annu. Rev. Entomol. 11: 123-154.

1966c. The accessory burrows of digger wasps. Science 152: 465-471.

Evans, H. E. and M. J. West Eberhard

1970. The Wasps. University of Michigan Press, Ann Arbor, Michigan.

FABRE, J. H.

1920. The Hunting Wasps. Dodd, Mead and Co., New York.

FrisCh, J. A.

1937. The life-history and habits of the digger-wasp Ammobia ichneumonea (Linn.). Amer. Midl. Natur. 18: 1043-1062.

1940. Did the Peckhams witness the invention of a tool by Ammophila urnaria? Amer. Midl. Natur. 24: 345-350.

GrisSell, E. E.

1981. Nesting behavior of Prionyx "thomae" (Fabricius) (Hymenoptera: Sphecidae). J. Kansas Entomol. Soc. 54: 16-21.

HaRTMan, C.

1905. Observations on the habits of some solitary wasps of Texas. Bull. Univ. Texas Sci. Ser. No. 7. 65: 1-73.

Hicks, C. H.

1932a. Nesting habits of Sphex xanthopterus (Cam.) (Hymen.) Can. Entomol. 64: 193-198.

1932b. Notes on Sphex aberti (Hald.) Can. Entomol. 64: 145-151.

1933. A study of Sphex breviceps (Smith) (Hymenop.). Can. Entomol. 65: 49-54.

1934. Biological notes on Sphex wrightii (Cresson). Psyche 41: 150-157. 
Holmes, S. J.

1911. The Evolution of Animal Intelligence. Henry Holt and Co., New York. HUNGERFORD, H. B. AND F. X. WiLliams

1912. Biological notes on some Kansas Hymenoptera. Entomol. News 23: 241-260.

Iwata, $K$.

1939. Habits of some solitary wasps in Formosa (IV). Trans. Nat. Hist. Soc. Formosa. 29: 161-169 (translation by Iwata).

1964. Bionomics of non-social wasps in Thailand. In Kira, T. and T. Umosao (eds.). Nature and Life in Southeast Asia. Fauna and Flora Research Society, Kyoto, Japan. 3: 323-383.

1976. Evolution of Instinct: Comparative Ethology of Hymenoptera. Smithsonian Institution, America Publ. Co., New Delhi.

KaZenas, V. L.

1968. On the biology of the digger wasp Sphex mocsaryi Kohl (Hymenoptera, Sphecidae). Entomol. Rev. 47: 492-493.

1970. The biology of the fossorial wasp Ammophila (Eremochares) dives Brullé (Hymenoptera, Sphecidae). Entomol. Rev. 49: 172-180.

KROMBEIN, K. V.

1936. Biological notes on some solitary wasps. (Hymenoptera: Sphecidae). Entomol. News 47: 93-99.

1952. Biological and taxonomic observations on the wasps in a coastal area of North Carolina (Hymenoptera: Aculeata). Wasmann J. Biol. 10: 257-341.

1955. Some notes on the wasps of Kill Devil Hills, North Carolina, 1954. Proc. Entomol. Soc. Wash. 57: 145-159.

1958. Biological notes on some wasps from Kill Devil Hills, North Carolina, and additions to the faunal list (Hymenoptera, Aculeata). Proc. Entomol. Soc. Wash. 60: 97-110.

1970. Behavioral and life-history notes on three floridian solitary wasps (Hymenoptera: Sphecidae). Smiths. Contrib. Zool. 46: 1-24.

LAMBURN, J. B.

1955. The Hunting Wasp. Houghton Mifflin Co., Boston, Massachusetts. LARIVERS, I.

1945. The wasp Chlorion laeviventris as a natural control of the mormon cricket. Amer. Midl. Natur. 33: 743-763.

McDougall, W.

1923. Outline of Psychology. Charles Scribner's Sons, New York. MenKe, A. S.

1965. The identity of some Ammophila observed by C. H. Hicks, H. E. Evans and others in connection with biological studies (Hymenoptera, Sphecidae). Entomol. News. 76: 257-261.

Menke, A. S. AND R. M. BoharT

1976. Sphecid wasps of the world: errors and omissions (Hymenoptera: Sphecidae). Proc. Entomol. Soc. Wash. 81: 111-124. 
MurRay, W. D.

1940. Podalonia (Hymenoptera: Sphecidae) of North and Central America. Entomologica Americana 20: 1-84.

NewCOMER, E. H.

1930. Notes on the habits of a digger wasp and its inquiline flies. Ann. Entomol. Soc. Amer. 23: 552-563.

Olberg, G.

1959. Das Verhalten der Solitären Wespen Mitteleuropas. VEB Deutscher Verlag der Wissenschaften, Berlin.

PARKer, J. B.

1915. Notes on the nesting habits of some solitary wasps. Proc. Entomol. Soc. Wash. 17: 70-76.

Peckham, G. W. and E. G. Peckham

1892. On the Instincts and Habits of the Solitary Wasps. Wisc. Geol. and Nat. Hist. Surv. Madison, Wisconsin.

Pergande, $T$.

1890. Peculiar habit of Ammophila gryphus Sm. Proc. Entomol. Soc. Wash. 2: 256-259.

Powell, J. A.

1964. Additions to the knowledge of the nesting behavior of North American Ammophila (Hymenoptera: Sphecidae). J. Kansas Entomol. Soc. 37: 240-258.

RAU, P.

1937. A note on the nesting habits of the roach-hunting wasp. Podium (Parapodium) carolina Rohwer (Hym). Entomol. News 48: 91-94.

RAU, P. AND N. RAU

1918. Wasp Studies Afield. Princeton Univ. Press, Princeton, New Jersey.

Ristich, S. S.

1953. A study of the prey, enemies and habits of the great-golden digger wasp Chlorion ichneumoneum (L.). Canad. Entomol. 85: 374-386.

SPANGleR, H. G.

1973. Vibration and soil manipulation in Hymenoptera. J. Kansas Entomol. Soc. 46: 157-160.

StrandTManN, R. W.

1945. Observations on the nesting habits of some digger wasps. Ann. Entomol. Soc. Amer. 38: 305-313.

STUCKer, G.

1953. Engineer of the insects-the digger wasp. Frontiers, A Magazine of Natural History (Phila.) 17: 137-139.

THORPE, W. H.

1956. Learning and Instinct in Animals. Methuen and Co. Ltd., London. Tilden, J. W.

1953. The digging and provisioning behavior of Ammophila saeva Smith (Hymenoptera: Sphecidae). Pan-Pac. Entomol. 29: 211-218. 
TsuneKI, $\mathbf{K}$.

1963a. Comparative studies on the nesting biology of the genus Sphex (s. 1.) in East Asia (Hymenoptera, Sphecidae). Mem. Fac. Liberal Arts, Fukui Univ. Ser. 2: 13-78.

1963b. A new study on the nesting biology of the tube-renting Ammophila, $A$. aemulans Kohl (Hymenoptera, Sphecidae). The Life Study (Fukui) 7: 44-48.

1968. The biology of Ammophila in east Asia (Hym., Sphecidae). Etizenia. Occ. Publ. Biol. Lab. Fukui Univ. Japan 33: 1-64.

Wheeler, G. C. AND E. H. WheELeR

1924. The use of a tool by a sphecid wasp. Science 59: 486. Williams, F. X.

1919. Descriptions of new species and life history studies. Hawaiian Sugar Planter's Assoc. Experiment Station Bull. Entomological Series 14: 19-186.

1928. Studies in tropical wasps-their hosts and associates. Hawaiian Sugar Planter's Assoc. Experiment Station Bull. Entomological Series 19: 112-151.

Williston, S. W.

1892. Note on habits of Ammophila. Entomol. News 3: 85-86.

WILSON, E. $O$.

1975. Sociobiology: the New Synthesis. The Belknap Press of Harvard University Press, Cambridge.

Species and References

(Tables 1A, 1B)

(Taxonomy after Bohart and Menke 1963, 1976

and Menke and Bohart 1979)

Sceliphrini

Stangeella cyaniventris (Guérin-Méneville)—Bohart and Menke 1976

Penepodium luteipenne (Fabricius) - Williams 1928

Sphecini

Sphex argentatus Fabricius-Tsuneki 1963a, Iwata 1964

Sphex ichneumoneus (L.)-Carpenter 1930, Frisch 1937, Ristich 1953, Brockmann 1976, 1980

Sphex muticus Kohl-Williams 1919

Sphex pensylvanicus L.-pers. obs.

Sphex subtruncatus Dahlbom-Tsuneki 1963a

Sphex Fernaldina lucae Saussure-Cazier and Mortenson 1965

Palmodes dimidiatus (De Geer)-Krombein 1952, 1955 (referred to as Palmodes daggyi)

Palmodes laeviventris (Cresson)-La Rivers 1945

Prionyx atratus (Lepeletier)-Peckham and Peckham 1898, Rau and Rau 1918, Carpenter 1930, Strandtmann 1945, Evans 1958

Prionyx kirbii (Vander Linden)-Benz 1959, Tsuneki 1963a (as P. albisectus) 
Prionyx subfuscatus (Dahlbom)-Evans 1958, Tsuneki 1963a

Prionyx thomae (Fabricius)-Rau and Rau 1918, Hartman 1905, Evans 1958 (as P. pubidorsum), Grissell 1981

Prionyx viduatus (Christ) - Kazenas 1968

Ammophilini

Podalonia spp.-Murray 1940

Podalonia hirsuta (Scopoli)-Carpenter 1930

Podalonia luctuosa (F. Smith)-Newcomer 1930

Podalonia pubescens Murray-pers. obs.

Podalonia violaceipennis (Lepeletier)-Parker 1915, Krombein 1936

Eremochares dives (Brullé)-Kazenas 1970, Bohart and Menke 1976

Eremnophila aureonotata (Cameron)-Peckham and Peckham 1898, Krombein 1958, Evans 1959

Ammophila aberti Haldemann-Williston 1892, Hicks 1932b, Evans 1959, 1963, Powell 1964, Menke 1965, pers. obs.

Ammophila azteca Cameron-Powell 1964 (as A. pilosa), Evans 1965, Evans and West Eberhard 1970

Ammophila clavus (Fabricius) - Iwata 1939, 1964, 1976, Tsuneki 1968

Ammophila harti (Fernald)-Evans 1959, Powell 1964, B. Hager (pers. comm.)

Ammophila heydeni Dahlbom-Thorpe 1956 (and references therein)

Ammophila juncea Cresson-Evans 1959, 1963, Powell 1964

Ammophila kennedyi (Murray)-Ainslie 1924 (as S. vulgaris)

Ammophila macra Cresson-Evans 1965

Ammophila pictipennis Walsh-Rau and Rau 1918, Carpenter 1930

Ammophila placida F. Smith-Hicks 1932a (as S. xanthopterus), Strandtmann 1945, Evans 1959, Powell 1964, Menke 1965

Ammophila procera Dahlbom-Pergande 1890 (as A. gryphus), Hartman 1905, Rau and Rau 1918, Wheeler and Wheeler 1924 (as A. gryphus), Carpenter 1930, Krombein 1952, Stucker 1953, Tilden 1953 (as A. saeva), Evans 1959, Powell 1964

Ammophila pruinosa Cresson-Hicks 1933, Evans 1959, Powell 1964

Ammophila pubescens Curtis-Baerends 1941 (as A. campestris), Adriaanse 1943 (as A. campestris), 1947, Olberg 1959

Ammophila sabulosa (L.)-Fabre 1920, Iwata 1939, Olberg 1959, Tsuneki 1968, Iwata 1976 (as $A$. infesta)

Ammophila urnaria Dahlbom-Peckham and Peckham 1898, Parker 1915, Frisch 1940, Evans 1959, Powell 1964, pers. obs.

Ammophila wrightii (Cresson)-Hicks 1934, Adriaanse 1947, Evans 1959, Olberg 1959, Powell 1964, Evans and West Eberhard 1970

Ammophila zanthoptera Cameron-Evans 1959, Powell 1964 

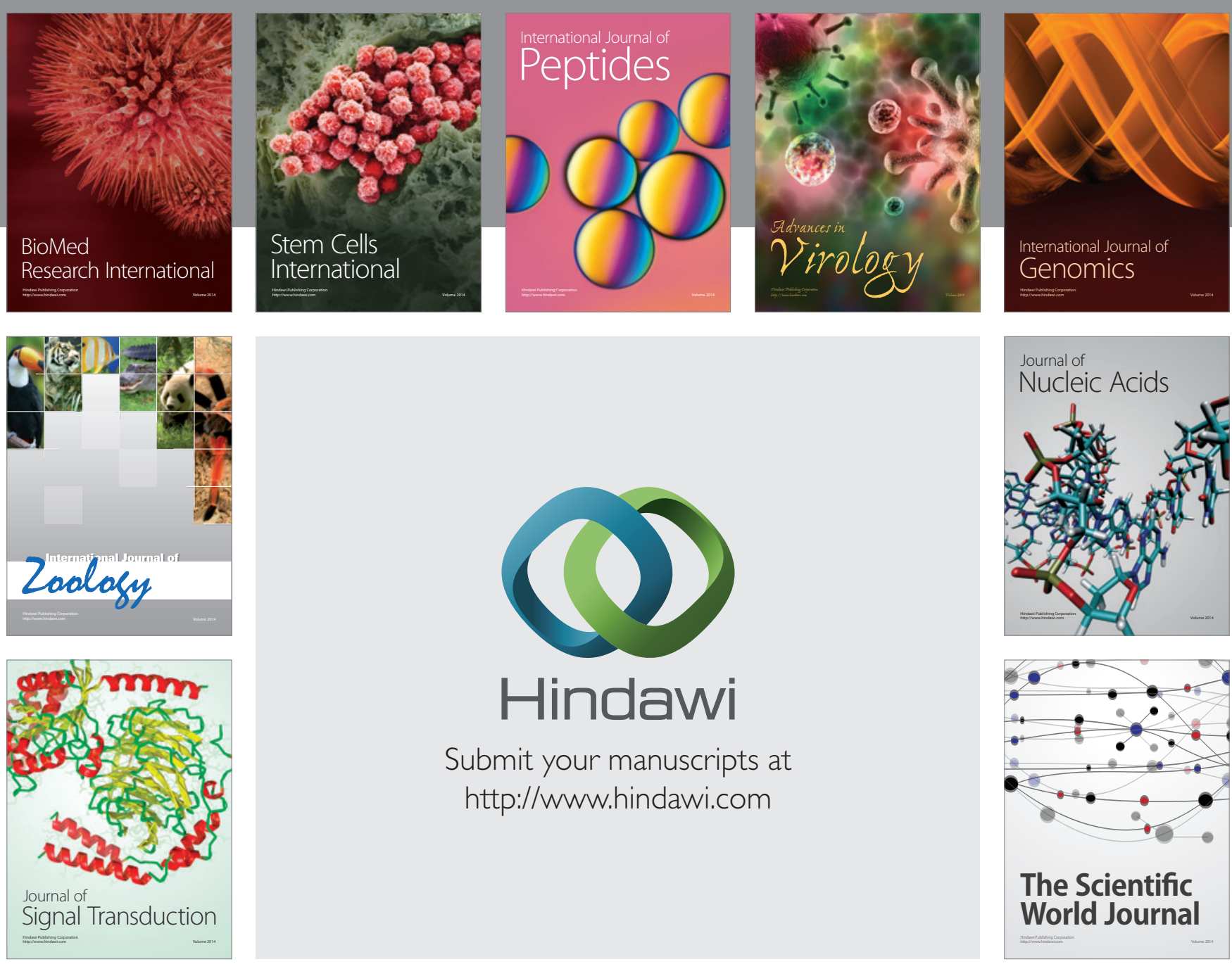

Submit your manuscripts at

http://www.hindawi.com
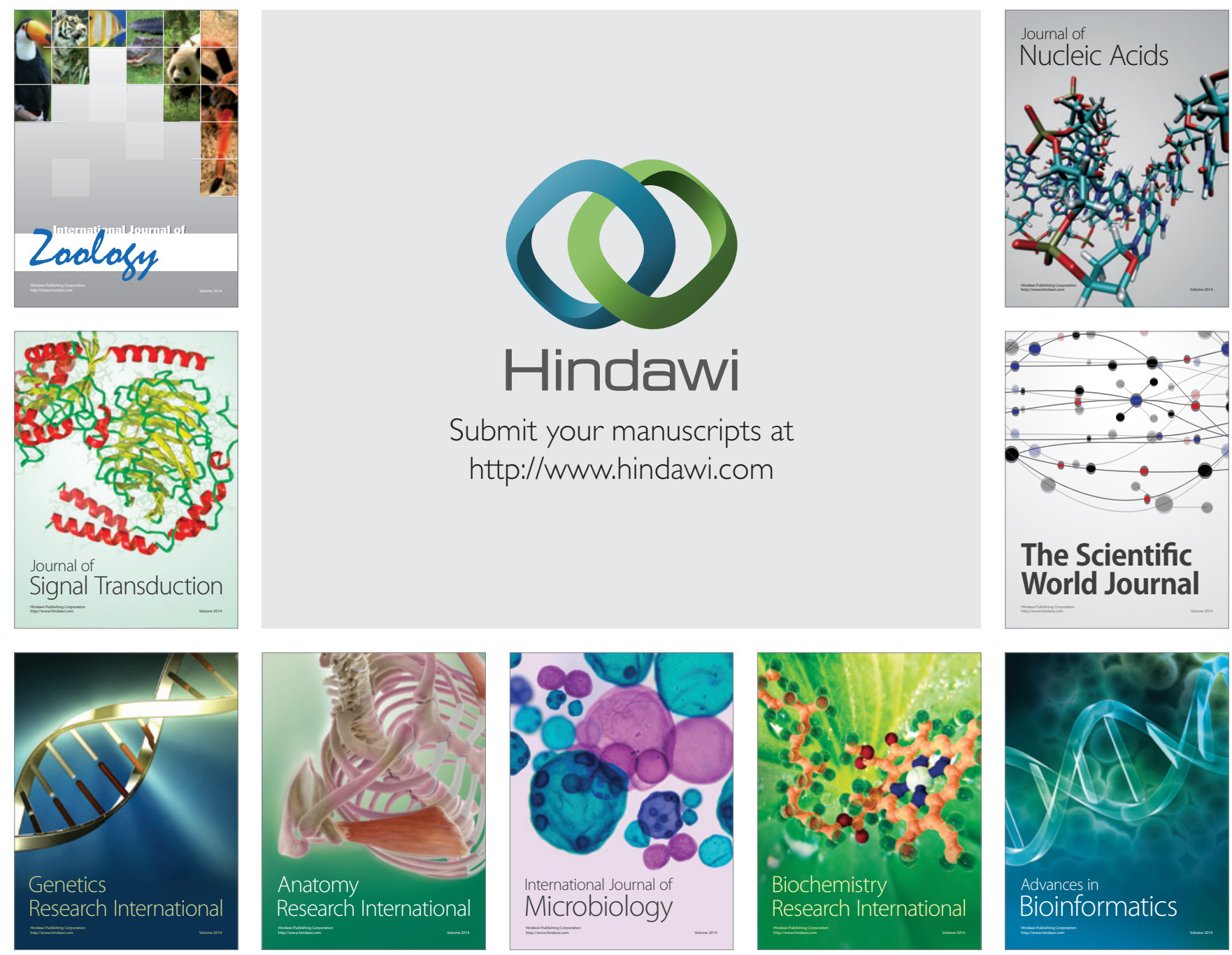

The Scientific World Journal
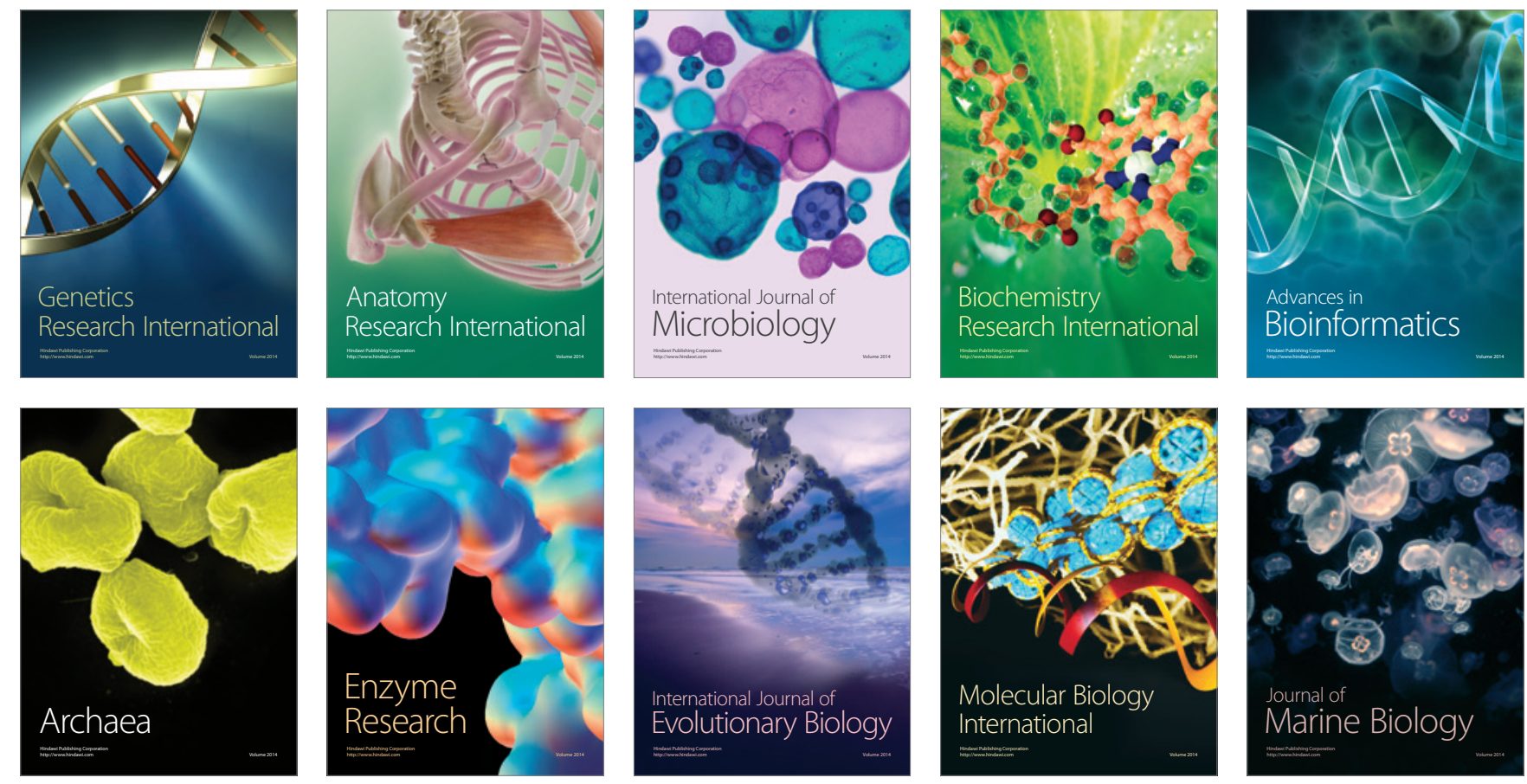